\title{
Control of primary productivity and the significance of photosynthetic bacteria in a meromictic kettle lake. Mittlerer Buchensee, West-Germany
}

\author{
Jörg Overmann ${ }^{1}$ and Max M. Tilzer \\ Limnologisches Institut Konstanz, FRG
}

Key words: Primary production; oligotrophy; photosynthetic bacteria; meromixis; kettle lake.

\begin{abstract}
During 1986 planktonic primary production and controlling factors were investigated in a small $\left(A_{0}=\right.$ $11.8 \cdot 10^{3} \mathrm{~m}^{2}, Z_{\max }=11.5 \mathrm{~m}$ ) meromictic kettle lake (Mittlerer Buchensee). Annual phytoplankton productivity was estimated to ca $120 \mathrm{gC} \cdot \mathrm{m}^{-2} \cdot \mathrm{a}^{-1}\left(1,42 \mathrm{tC} \cdot \mathrm{lake}^{-1} \cdot \mathrm{a}^{-1}\right)$. The marked thermal stratification of the lake led to irregular vertical distributions of chlorophyll $a$ concentrations (Chla) and, to a minor extent, of photosynthesis $\left(\mathrm{A}_{\mathrm{z}}\right)$. Between the depths of 0 to $6 \mathrm{~m}$ low Chla concentrations $\left(<7 \mathrm{mg} \cdot \mathrm{m}^{-3}\right)$ and comparatively high background light attenuation $\left(\mathrm{k}_{\mathrm{w}}=0,525 \mathrm{~m}^{-1}, 77 \%\right.$ of total attenuation due to gelbstoff and abioseston) was found. As a consequence, light absorption by algae was low (mean value $17,4 \%$ ) and self-shading was absent.

Because of the small seasonal variation of Chla concentrations, no significant correlation between Chla and areal photosynthesis ( $\Sigma A$ ) was observed. Only in early summer (June-July) biomass appears to influence the vertical distribution of photosynthesis on a bigger scale. Around $8 \mathrm{~m}$ depth, low-light adapted algae and phototrophic bacteria formed dense layers. Due to low ambient irradiances, the contribution of these organisms to total primary productivity was small. Primary production and incident irradiance were significantly correlated with each other $\left(r^{2}=0.68\right)$. Although the maximum assimilation number $\left(P_{\text {opt }}\right)$ showed a clear dependence upon water temperature $\left(Q_{10}=2.31\right)$, the latter was of minor importance to areal photosynthesis.
\end{abstract}

\section{Introduction}

In ecosystems, the primary productivity integral is controlled by incident radiation, temperature of the environment and nutrients, as well as biomass and the physiological states of the plants. In aquatic environments photosynthetic organisms have to compete with the optically dense medium for light energy (Tilzer et al. (1975), Wetzel (1983), Odum (1983)). Therefore, not only the total biomass of algae per unit of lake surface but also its vertical distribution (biomass concentration) has a direct influence on the light utilization efficiency of phytoplankton (Tilzer et al. (1975)). Numerous small lakes of glacial origin are found in the surroundings of Lake Const-

\footnotetext{
1 Present address: Lehrstuhl für Mikrobielle Ökologie, Universität Konstanz, Postfach 5560, D-7750 Konstanz 1, FRG.
} 
ance, which is situated at the northern fringe of the European Alps. Located to the West of Lake Constance, Mittlerer Buchensee represents a small kettle lake without any silt-load. So far, only seasonal cycles of water temperature, oxygen concentrations and zooplankton development were investigated (Einsle (1966), Einsle (1969)). In 1986, the annual variations of important limnological parameters were examined by four simultaneous studies (Fitz (1987), Holler (1987), Overmann (1987), Barthelmeß (1988)). This paper deals with the underwater light field, the amount and distribution of photosynthetic pigments as well as photosynthetic activity of phytoplankton and photosynthetic bacteria.

\section{Materials and methods}

Mittlerer Buchensee is located at $430 \mathrm{~m}$ a.s. 1 . in the terminal moraines of the last glaciation (Würm). It has a circular shape (shoreline development $D_{L}=1.04$ ) and is deep in relation to its surface area (surface area $A_{o}=1.18$ ha, maximum depth $11.5 \mathrm{~m}$, mean depth $7.1 \mathrm{~m}$ ). Owing to this and the relatively sheltered location, the lake is meromictic with a sharp chemocline at a depth of ca $8 \mathrm{~m}$. The drainage area is small $\left(1.5 \mathrm{~km}^{2}\right)$ and the theoretical water retention time $1.3-2.7$ years (Overmann (1987)).

Samples were collected over the deepest part at 28 dates, beginning after break-up of the ice cover end of March 1986 until December 1986. Temperature was measured using a thermistor probe (YSI, Model 57), $\mathrm{pH}$ with a transportable Metrohm E 488 (equipped with an Ingold U 455 electrode) and conductivity with the LF DIGI 550 (WTW), after returning to the laboratory.

Dissolved inorganic carbon (DIC) was assessed by acidimetric titration using the tables of Rebsdorf (1972). If samples contained $\mathrm{H}_{2} \mathrm{~S}$, DIC was computed using the procedure of Brunskill (1969), determining $\mathrm{H}_{2} \mathrm{~S}$ with the methylene blue method (Deutsche Einheitsverfahren (1982)).

Secchi readings were performed around solar noon using a white disc $35 \mathrm{~cm}$ in diameter. Quantum fluxes during incubation time, per day and daily means for the entire week were calculated based on Star pyranometer records of the Limnological Institute Konstanz. Energy was converted to quanta by assuming a mean wavelength of solar radiation of $550 \mathrm{~nm}$ and photosynthetically active radiation to comprise $46 \%$ of total short-wave radiation (Tilzer (1983), Tilzer and Beese (1988)). Measurements of downwelling photosynthetically active radiation (PAR, 400-700) were performed with the LiCor quantum meter (Model 185B) between 11.00 and 13.00 hours.

Chlorophyll $a$ concentrations (Chla) were determined spectrophotometrically (Zeiss PM4) from hot ethanol extracts after filtering lake water through glass fiber filters (Schleicher \& Schüll, $\varnothing 50 \mathrm{~mm}$ ). For computation, monochromatic equations which take into account also the accompanying pheopigment concentrations were used (Nusch (1980)).

After cold extraction of bacteriochlorophyll (Bchl) $a, d$, e in acetone $(99.5 \%$ p. a., $4{ }^{\circ} \mathrm{C}, 8$ hours), concentrations of Bchla could be calculated applying the equations given by Steenbergen and Korthals (1982). As the absorption coefficient of 
Bchle is not known and its absorption peak is located close to Bchld, both pigments were treated identically (Steenbergen and Korthals (1982)). Chla often was found in significant amounts together with bacterial pigments. In order to exactly determine pigment concentrations (Bchld $+e, \mathrm{Chl} a$ ) in these cases as well, dichromatic equations had to be used. All known equations (e.g. Parkin and Brock (1981), Caraco and Puccoon (1986)) failed to give reasonable results. Therefore, new dichromatic equations were derived by spectrophotometric analysis of extracts containing solely Bchld $+e$ or Chl $a$ (Shimadzu UV-300) and calculation of correction coefficients based upon absorption ratios at 651 and $663 \mathrm{~nm}$ (Overmann (1987)):

$$
\begin{aligned}
& \text { Bchl }(\mathrm{d}+\mathrm{e})=\left(1.315 \cdot \mathrm{E}_{651}-0,643 \cdot \mathrm{E}_{663}+0,005\right) \cdot \mathrm{v} \cdot 10^{6} /\left(\mathrm{V} \cdot \mathrm{d} \cdot \varepsilon_{\mathrm{Bchld}}\right) \\
& \text { Chl a }=\left(1.315 \cdot \mathrm{E}_{663}-0,643 \cdot \mathrm{E}_{651}+0,005\right) \cdot \mathrm{v} \cdot 10^{6} /\left(\mathrm{V} \cdot \mathrm{d} \cdot \varepsilon_{\mathrm{Chl} a}\right)
\end{aligned}
$$

where:

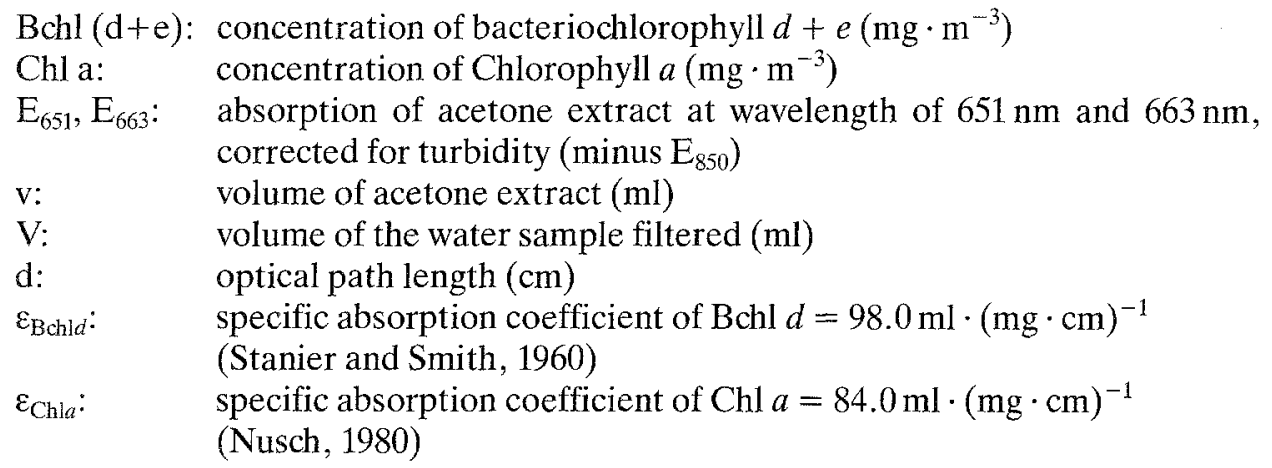

Employing a regression analysis of vertical light attenuation $\left(\mathrm{k}_{\mathrm{D}}\right)$ versus Chla (plus pheopigments), these field data allowed us to evaluate the chlorophyll-specific attenuation coefficient $\mathbf{k}_{\mathrm{c}}$ (Tilzer (1983), Megard et al. (1979), Dubinsky and Berman (1979), Dubinsky and Berman (1981), Meffert and Overbeck (1985)).

Photosynthetic measurements were conducted at 1-meter depth intervals between the lake surface and $10 \mathrm{~m}$ depth by using a modified ${ }^{14} \mathrm{C}$-technique (Tilzer (1988), Steemann-Nielsen (1952)). Incubations lasted from 10.00 to 13.00 hours each. To estimate daily rates of primary productivity and daily means for the entire week, corresponding quantum fluxes (see above) were used following the logarithmic lightdivision hour method of Talling (1971).

For detailed investigation of photosynthetic activity within the aerobic-anaerobic boundary layer, an additional incubation rack (total length $1.5 \mathrm{~m}$; distance between horizontal incubation bottles $9 \mathrm{~cm}$; volume of bottles $50 \mathrm{ml}$ ) was used (for further information see Overmann (1987)). In this case values of carbon uptake in the dark bottles were not substracted from light uptake values to evaluate the vertical distribution of both parameters separately. Furthermore, various laboratory experiments were conducted at different temperature and light conditions (see below). 


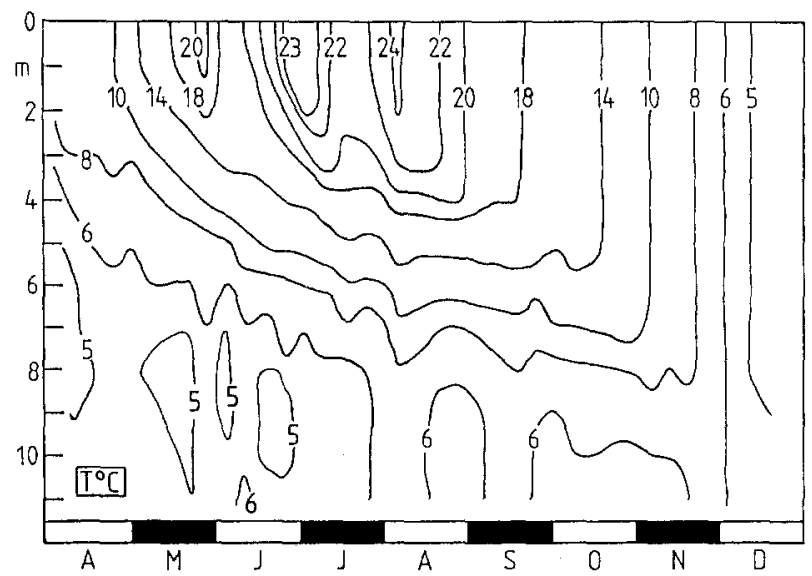

Figure 1. Temperature isopleths $\left({ }^{\circ} \mathrm{C}\right)$ of Mittlerer Buchensee in 1986.

\section{Results}

\subsection{General description of the lake}

Thermal stratification of the lake was sharp during summer (Fig.1). Until September the thermocline extended from 3 to $8 \mathrm{~m}$ depth and in October still from 4.5 to $8 \mathrm{~m}$. In summer an inverse stratification of the water temperature was observed beneath $9 \mathrm{~m}$, reaching a maximum gradient of $0.8^{\circ} \mathrm{C} \mathrm{m}^{-1}$ at the lake bottom. Isothermal conditions over the entire water column could be found only on one day of measurement (December 2, 1986). On that date, conductivity measurements, oxygen saturation (Fig. 2) and $\mathrm{NH}_{4}$ and $\mathrm{H}_{2} \mathrm{~S}$ values still showed vertical inhomogeneity, giving evidence for remaining chemical stratification. This suggests that Mittlerer Buchensee is meromictic.

\subsection{Underwater light climate}

In natural waters, the amount of photosynthetically active radiation (PAR) is governed by incident solar radiation $\left(I_{0}\right)$ and the light attenuation properties of the lake water (vertical attenuation coefficient of downwelling irradiance $\mathrm{k}_{\mathrm{D}}$ ). Figure $3 \mathrm{a}$ depicts the pattern of $I_{0}$ during the investigation period. Values of $I_{0}$ during the actual day of measurement as well as mean daily values of the respective week are given. Secchi depth and light transmission are shown in Fig. 3 b. Water transparency increased twofold in June and showed a decrease at the end of August. Within the upper 6 meters of the water column $\mathrm{k}_{\mathrm{D}}$ assumed values between $0.5-0.86 \mathrm{~m}^{-1}$. Secchi readings $\left(z_{\mathrm{s}}\right)$ ranged from 1 to $4.8 \mathrm{~m}$ (mean value $2.5 \mathrm{~m}, \mathrm{~S} . \mathrm{D} . \pm 35 \%$ ). In other lakes, a correlation between euphotic depths $\left(\mathrm{z}_{\mathrm{eu}}\right.$ : depth where underwater light is $1 \%$ of the surface value) and Secchi depths was observed (Tilzer (1988)). In the case of Mittlerer Buchensee, no close relationship between both parameters was apparent (cf Table 1). 


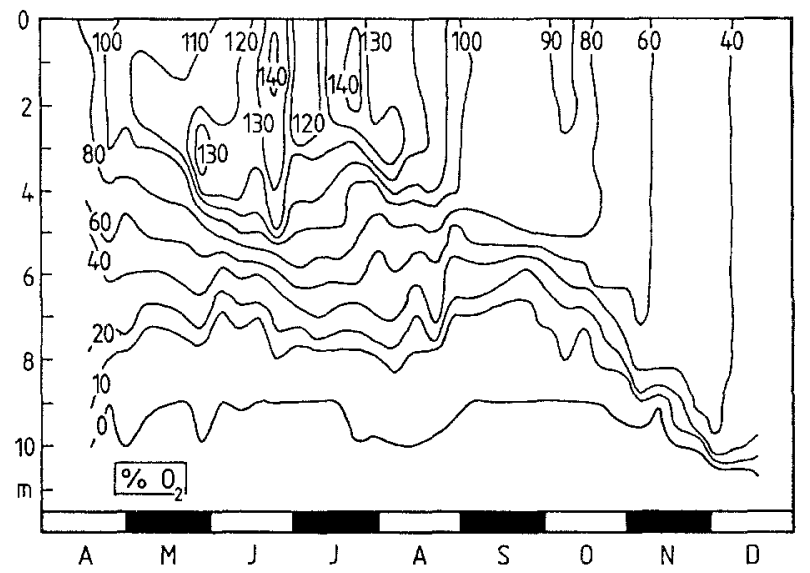

Figure 2. Isopleths of oxygen saturation relative to the atmosphere (in percent) of Mittlerer Buchensee in 1986.

The bottom plot (Fig. $3 \mathrm{c}$ ) illustrates resulting seasonal variations of underwater irradiance (assuming a 10\% loss of incident solar radiation through reflection at the lake surface). The vertical attenuation of light was uniform between the lake surface and $7 \mathrm{~m}$ depth. Below, a marked increase of light attenuation was apparent, especially between June and October. During the investigation period, light transmission of the water column showed only minor changes with time.

A linear regression analysis of the light attenuation coefficient $\left(\mathrm{k}_{\mathrm{D}}\right)$ versus chlorophyll concentration was used for the computation of the chlorophylla-specific light attenuation coefficient $\left(\mathrm{k}_{\mathrm{c}}\right)$ :

$$
\begin{aligned}
& \mathrm{k}_{\mathrm{D}}=\mathrm{k}_{\mathrm{w}}+\mathrm{k}_{\mathrm{c}} \cdot \mathrm{Chl} a \\
& \mathrm{k}_{\mathrm{w}}=(0.530 \pm 0.044) \mathrm{m}^{-1}, \mathrm{k}_{\mathrm{c}}=(0.020 \pm 0.004) \mathrm{m}^{2} \cdot \mathrm{mgChla}^{-1} \\
& \left.\mathrm{r}^{2}=0.788^{* * *} ; \mathrm{n}=31 ; 95 \% \text { level of significance }\right)
\end{aligned}
$$

From this, a value of $\mathrm{k}_{\mathrm{c}}=0.020 \cdot \mathrm{m}^{2} \cdot \mathrm{mgChl} a^{-1}$ can be derived. Backround light attenuation $\left(\mathrm{k}_{\mathrm{w}}\right)$ was comparatively high with $0.530 \mathrm{~m}^{-1}$. Within the upper $5 \mathrm{~m}$ of the water column, on the average $17.4 \%$ of underwater light was absorbed by photosynthetic pigments $\left(\mathrm{k}_{\mathrm{c}} \cdot \mathrm{Chl} a / \mathrm{k}_{\mathrm{D}}=0.174\right)$ (Bannister (1974)).

As with $z_{\mathrm{eu}}$, the Secchi depth was not correlated with mean Chla concentrations in the uppermost 4.5 meters $\left(\mathrm{Chl} a_{4.5}\right)$ (Tab. 1$)$.

\subsection{Distribution of phytoplankton and photosynthetic pigments}

Vertical and temporal variations of photosynthetic pigments are shown in Figures 4 a and 5. Following a downward movement of the bulk of chlorophylla from May to July, the chlorophyll $a$ concentration increased in upper water layers during late July and August. Shifting of the chlorophyll $a$ peak in spring can be attributed to sinking of the spring algae (St.hantzschii, St.binderanus, Scenedesmus sp., Rh. minuta) 
(a)

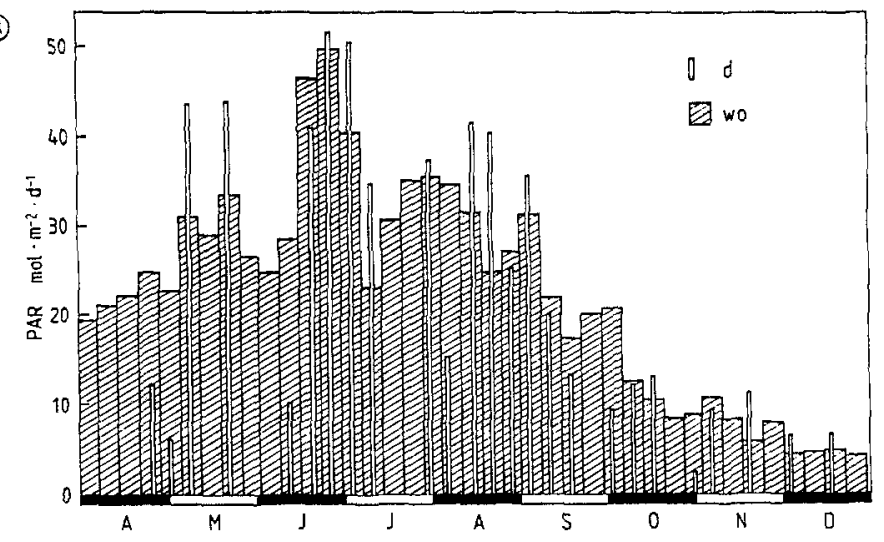

(b)

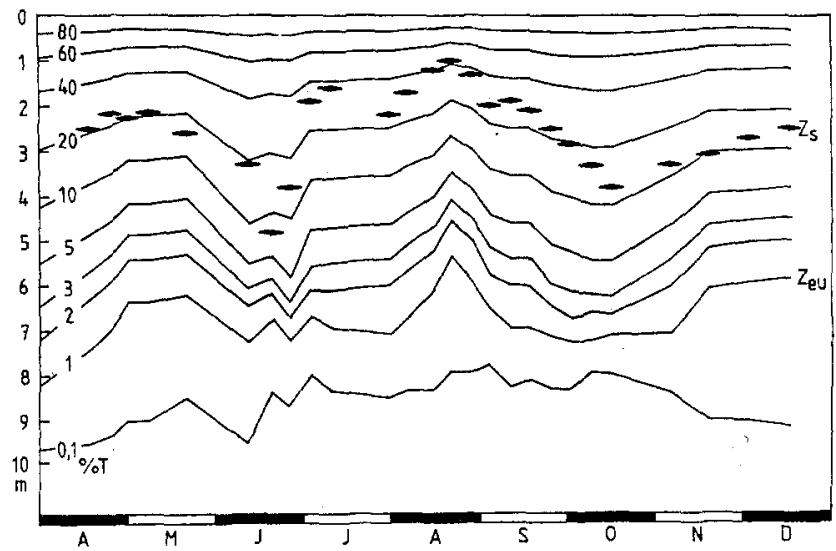

(c)

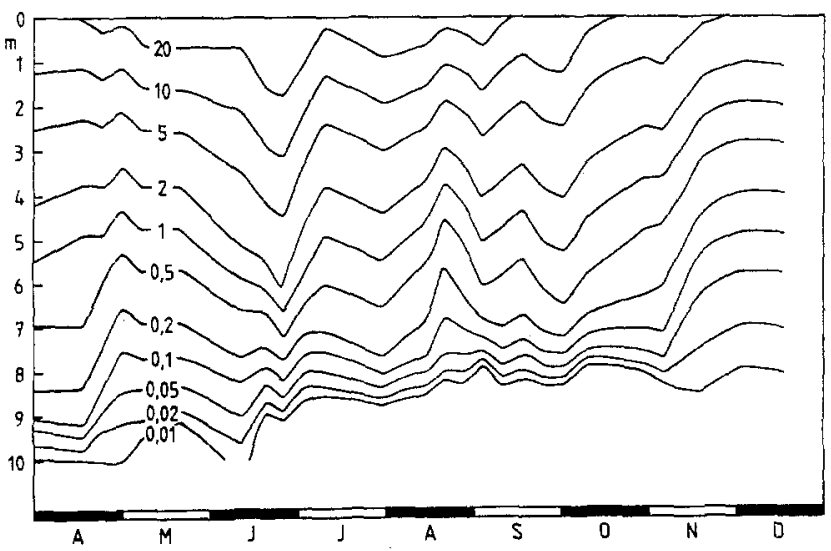

Figure 3. Seasonal and vertical distribution of photosynthetically active radiation (PAR) in 1986. Top: Incident daily quantum fluxes at days of photosynthetic measurements (d) and mean values for the respective week (wo). Middle: Isopleths of percentage transmission of surface light ( $\% \mathrm{~T})$. Values of secchi depth $\left(z_{\mathrm{s}}\right)$ and euphotic depth $\left(z_{\mathrm{eu}}=1 \% \mathrm{I}_{\mathrm{o}}{ }^{\prime}\right)$ are given. Bottom: Resulting seasonal and vertical distribution of underwater quantum fluxes. Values given are in molPAR $\cdot \mathrm{m}^{-2} \cdot \mathrm{d}^{-1}$. 
Table 1. Analysis of correlations between various limnological parameters.

\begin{tabular}{|c|c|c|c|}
\hline parameters & equation & $\mathrm{r}^{2}$ & $\mathrm{n}$ \\
\hline$z_{\mathrm{eu}} / z_{\mathrm{s}}$ & $\mathrm{z}_{\text {eu }}=5,92 \cdot\left(\mathrm{z}_{\mathrm{s}}\right)^{0,14(1)}$ & 0,28 & 27 \\
\hline$z_{8} / \mathrm{Chla}_{(4,5)}$ & $\mathrm{z}_{\mathrm{s}}=5,93 \cdot\left(\mathrm{Chla}_{(4.5)}\right)^{-0,58(2)}$ & 0,25 & 26 \\
\hline $\mathrm{P}_{\mathrm{opt}} / \mathrm{T}$ & $\log P_{\text {opt }}=-0,38+0,04 \cdot \mathrm{T}$ & 0,79 & 24 \\
\hline$\Sigma A / A_{o p t}$ & $\Sigma \mathrm{A}=3,35+3,15 \cdot \mathrm{A}_{\mathrm{opt}}$ & 0,76 & 22 \\
\hline$\Sigma \mathrm{A} / \mathrm{T}_{\mathrm{opt}}$ & $\Sigma \mathrm{A}=9,79+1,76 \cdot \mathrm{T}_{\mathrm{opt}}$ & 0,55 & 22 \\
\hline$\Sigma \mathrm{A} / \mathrm{I}_{0}{ }^{\prime}$ (inc) & $\Sigma A=18,88+0,008 \cdot I_{0}{ }^{\prime}(\text { inc })^{(3)}$ & 0,68 & 25 \\
\hline$T_{\text {opt }} / I_{o}^{\prime}($ inc) & $\mathrm{T}_{\mathrm{opt}}=10,11+0,002 \cdot \mathrm{I}_{\mathrm{o}}^{\prime}(\mathrm{inc})$ & 0,41 & 22 \\
\hline$\Sigma \mathrm{A} / \mathrm{Ch}_{\mathrm{eu}}$ & $1 / \Sigma \mathrm{A}=0,02+0,068 \cdot 1 / \mathrm{Chl}_{\mathrm{e}}$ & 0,03 & 22 \\
\hline
\end{tabular}

formula as given by Tilzer, 1988

2 formula as given by Lorenzen, 1980

${ }^{3} I_{0}{ }^{\prime}=0.9 \cdot I_{0}$, value during 1 hour of incubation

(Fitz (1987)). From the end of June till the beginning of November, the maximum of chlorophyll $a$ concentration was measured between 7 and 9 meters reaching values of more than $25 \mathrm{mg} \cdot \mathrm{m}^{-3}$. According to Fitz (1987) Cryptomonas ovata, Oscillatoria tenuis and Lyngbya limnetica were dominant within these strata. Coccoid cyanobacteria (values taken from Holler (1987)) at times contributed more than $50 \%$ to the total biomass of chlorophyll $a$-containing phototrophs at $8 \mathrm{~m}$ depth. Until October, a remarkable fraction of chlorophyll $a$ was found below the euphotic zone. From October onward, deeper mixing of the lake caused homogeneous chlorophyll distribution down to the maximum depth of mixing. Unlike in other lakes (Lorenzen 1965)), the proportion of pheopigments in total pigments did not increase with depth.

The vertical and temporal variation of cellular chlorophyll $a$ content of algal biomass $\left(\mathrm{C}_{\mathrm{B}}, \mu \mathrm{gChla} \cdot \mathrm{mm}^{-3}\right)$ is shown in Fig. $4 \mathrm{~b}$. For computation, biomass values of algae and cyanobacteria as given by Fitz (1987) and Holler (1987) were used. Beginning in June, cellular chlorophyll $a$ contents decreased in shallow water $(0-7 \mathrm{~m})$ and remained low until October. The distribution pattern was similar to that of chlorophyll concentrations (Fig. 4 a). Our values $\left(1.5-11 \mu \mathrm{g} \cdot \mathrm{mm}^{-3}\right.$ ) are in agreement with those reported previously (Talling (1966): $4-5.3 \mu \mathrm{g} \cdot \mathrm{mm}^{-3}$, Tilzer and Goldman (1978): 0.61-4.97, Foy (1987): 1-6, max. $30 \mu \mathrm{g} \cdot \mathrm{mm}^{-3}$ ).

In vivo-spectroscopy of water samples taken from $8-10 \mathrm{~m}$ and concentrated in the centrifuge indicated the presence of accessory pigments characteristic of phototrophic bacteria: phycoerythrin and phycocyanin (cyanobacteria), okenone (Chromatiaceae: Amoebobacter purpureus, Eichler and Pfennig (1988)) and Isorenieratene/ $\beta$-Isorenieratene (brown members of the Chlorobiaceae: Pelodictyon, Pelochromatium). Epifluorescence microscopy revealed the presence of cyanobacteria by the orange autofluorescence of phycoerythrin (French and Young (1952)).

During summer and autumn 1986 the species composition of the phototrophic bacteria remained essentially constant. At this time Amoebobacter purpureus, two species of the genus Chloronema and in deeper layers Pelodictyon phaeoclathratiforme (Overmann and Pfennig (1989)) were dominating. After November cells of Pelodictyon phaeoclathratiforme and Pelochromatium sp. dominated. 

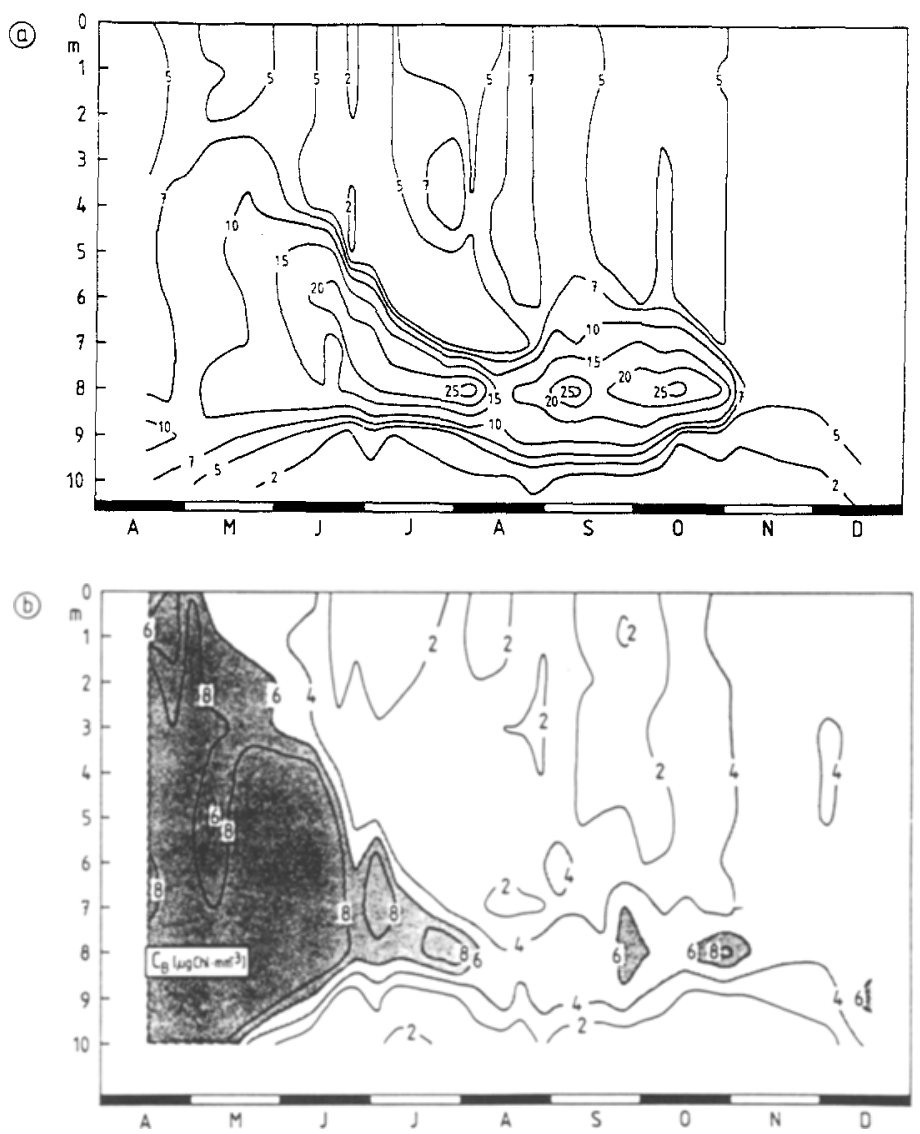

Figure 4. Seasonal and vertical distribution of chlorophyll $a$ concentration in lake water (upper panel, values of isopleths in $\mathrm{mg} \cdot \mathrm{m}^{-3}$ ) and of cellular chlorophyll $a$ content $\mathrm{C}_{\mathrm{B}}$ of phytoplankton (bottom panel, in $\left.\mu \mathrm{gChla} \cdot \mathrm{mm}^{-3}\right)$.

Results of quantitative measurements (at $10 \mathrm{~cm}$ intervalls) of bacteriochlorophyll $a$, $d$ and $e$ are shown in Fig. 5. Maximum concentrations of bacteriochlorophyll $a$ were found in or above $9 \mathrm{~m}$, those of bacteriochlorophylls $d+e$ in or beneath $9 \mathrm{~m}$. For the latter much higher concentrations were found as compared to bacteriochlorophyll $a$.

\subsection{Distribution of oxygenic photosynthesis}

Photosynthetic rates $\left(A_{z}\right)$ exhibited distinct vertical and seasonal variations (Fig. 6). Deep maxima of photosynthesis were observed in May/June $(5 \mathrm{~m})$ and July $(7 \mathrm{~m})$. Thereafter, photosynthetic rates near the surface increased to the highest value of the year with a light-saturated photosynthetic rate of $22.0 \mathrm{mgC} \cdot \mathrm{m}^{-3} \cdot \mathrm{h}^{-1}$ (20th of August).

Secondary maxima of photosynthesis could be observed at 7 or 8 meters depth on 

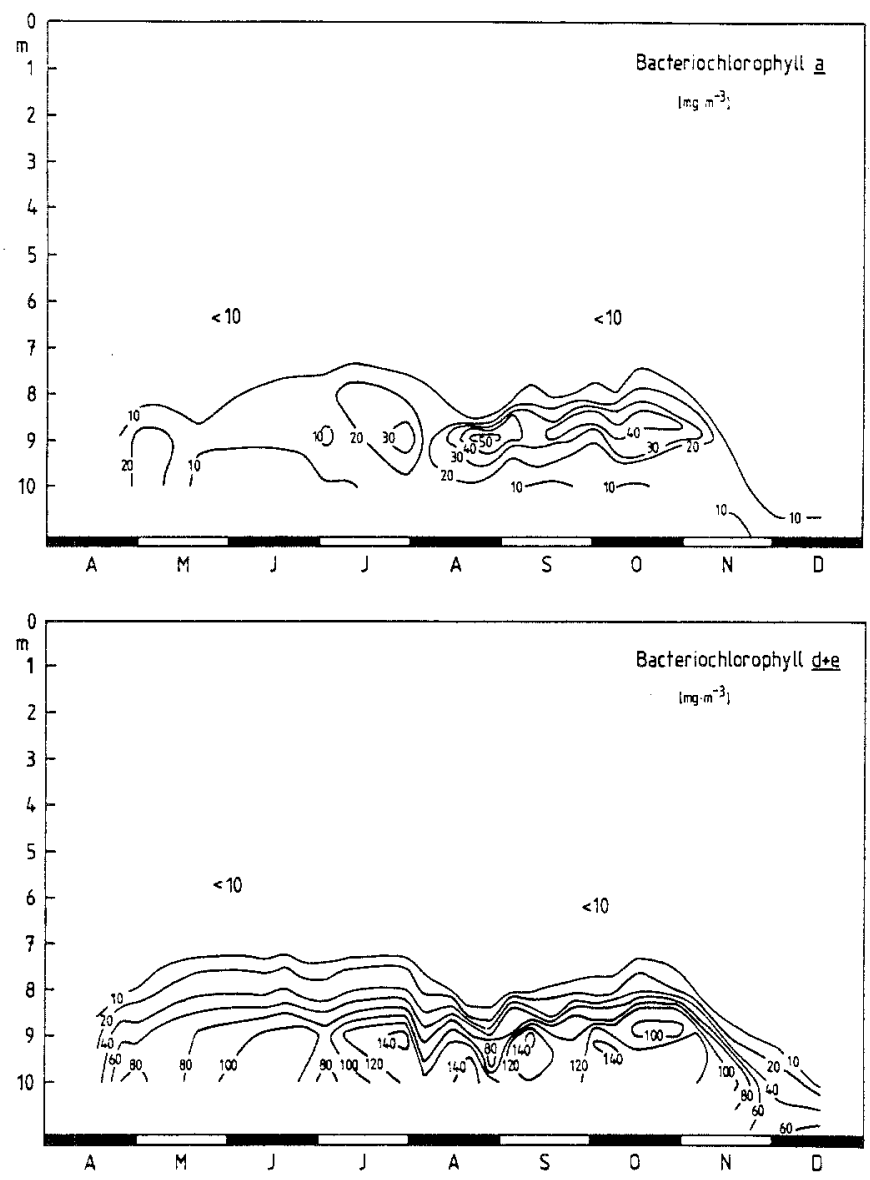

Figure 5. Isopleths of bacteriochlorophylls $a$ (Bchla, upper panel) and $d+e(\mathrm{Bchl} d+e$, bottom panel) in 1986.

several occasions. As late as November, when vertical mixing extended down to the $8 \mathrm{~m}$ layer, profiles of a more regular type were observed. No distinct maxima of photosynthetic rates were obtained on rainy days with very little incident radiation (end of April, mid September, end of October; Fig. 6).

If productivity over longer periods is to be computed, surface irradiance not only on the days of measurement but for the entire period in question have to be used. As shown in Fig. 3, irradiances on the days of measurement deviated significantly from the mean values obtained from continuous records during the corresponding week. Considering these mean values of irradiance, weekly averages of areal photosynthesis were calculated, which sometimes differed significantly from daily photosynthetic rates (Fig.7). Therefore, the weekly averages of areal photosynthesis have been used for the computation of primary productivity of the entire investigation period of 236 days. The resulting value for this time interval was ca $100 \mathrm{gC} \cdot \mathrm{m}^{-2}$. Since the ice cover broke up relatively late (March 20) in 1986 and incident radiation 


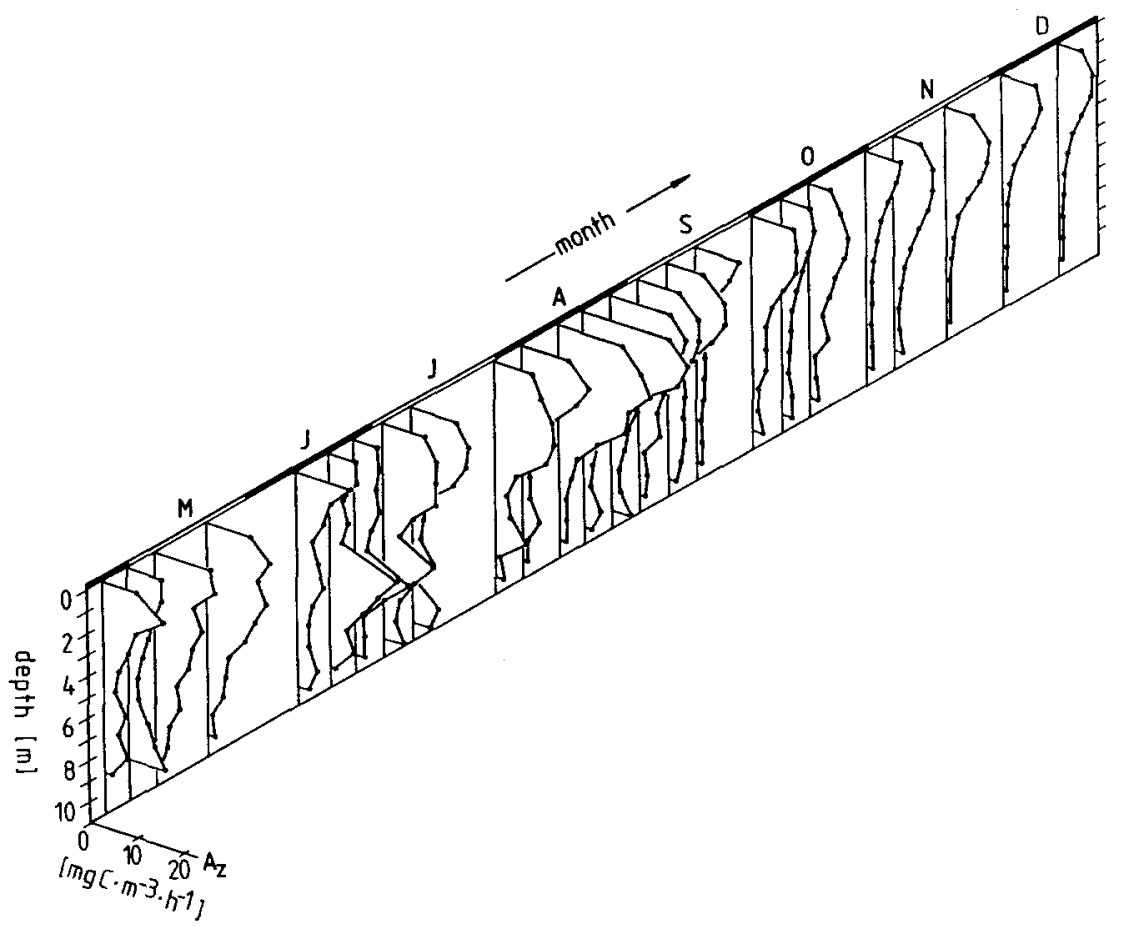

Figure 6. Depth-time distribution of photosynthetic rates $A_{z}$ during the investigation period. Interval between depths of measurements $=1 \mathrm{~m}$.

was low (as was phytoplankton biomass: $<1000 \mathrm{~mm}^{3} \cdot \mathrm{m}^{-2}$; Fitz (1987)), an annual primary productivity of over $120 \mathrm{gC} \cdot \mathrm{m}^{-2} \cdot \mathrm{a}^{-1}\left(=1.42 \mathrm{tC} \cdot\right.$ lake $^{-1}$, applying morphometric corrections) is unlikely.

Total light utilization efficiency ( $\left.\mathrm{E}_{\mathrm{TOT}}\right)$ is the ratio of integral photosynthesis beneath $1 \mathrm{~m}^{2}$ lake surface (expressed in energy equivalents) to the respective light energy impinging on $1 \mathrm{~m}^{2}$ lake surface at the same time. For the entire study period, an efficiency of photosynthetic light utilization of $0.29 \%$ was calculated.

The photosynthetic rate at a certain depth $\mathrm{z}$ of the water column $\left(\mathrm{A}_{\mathrm{z}}\right)$ depends on the concentration of photosynthetic pigments $(\mathrm{Chl} a)$ and on the chlorophyll-specific assimilation rate $\mathrm{P}_{\mathrm{z}}\left(\mathrm{mgC} \cdot \mathrm{mgCh}^{-1} \cdot \mathrm{h}^{-1}\right)$ :

$$
\mathrm{A}_{\mathrm{z}}=\mathrm{Chl} a \cdot \mathrm{P}_{\mathrm{z}}
$$

Between May and July, profiles of chlorophyll $a$ concentration and photosynthetic rates displayed similar trends with respect to their vertical distributions. In Fig. 8 some profiles of photosynthetic rates $\mathrm{A}_{\mathrm{z}}$ are compared with those of chlorophyllspecific assimilation rates $\mathrm{P}_{\mathrm{z}}$. The deep maxima in photosynthesis on $19^{\text {th }}$ and $25^{\text {th }}$ June as well as on $29^{\text {th }}$ July were obviously caused by deep chlorophyll maximum rather than by high chlorophyll-specific photosynthesis which on these dates in fact decreased with depth, giving evidence for light limitation. Later in the year, $A_{z}$ and $\mathbf{P}_{\mathrm{z}}$ showed more similar vertical distributions. 


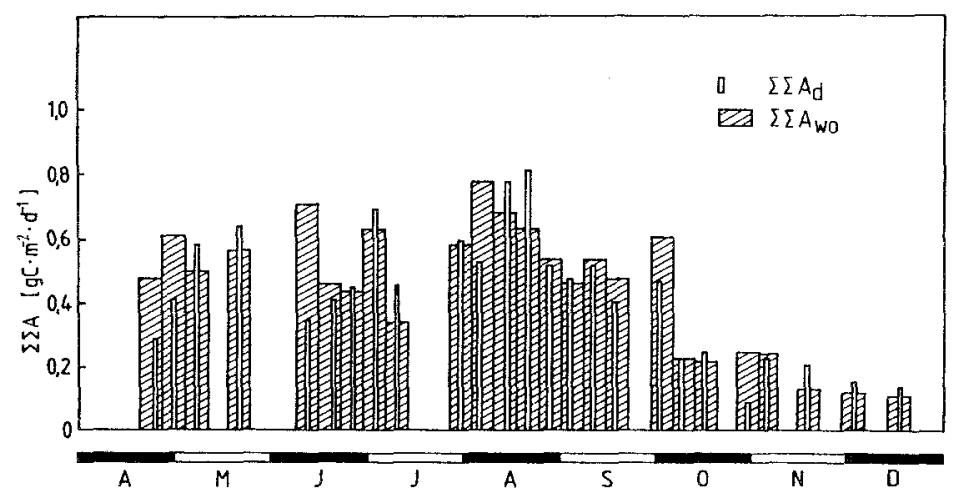

Figure 7. Time course of daily integrals of primary productivity $\Sigma \Sigma \mathrm{A}$. Values for days of measurement $\left(\Sigma \Sigma \mathrm{A}_{\mathrm{d}}\right)$ as well as mean daily values of the respective week $\left(\Sigma \Sigma \mathrm{A}_{\mathrm{wo}}\right)$ are given.

It is well established that light-saturated photosynthesis is temperature dependent. Table 1 shows a close (ca $80 \%$ ) correlation of the maximum chlorophyll-specific assimilation rate $\mathrm{P}_{\text {opt }}$ with water temperature at the depth of $\mathrm{P}_{\text {opt }}\left(\mathrm{T}_{\text {opt }}\right)$. From our data, $\mathrm{a} \mathrm{Q}_{10}$ of $2.31 \pm 0.44$ (95\% confidence limits) was derived which is similar to the values found by Williams and Murdoch (1966) and Talling (1979).

Although there is also a relationship between maximum photosynthetic rate $A_{\max }$ and areal photosynthesis during 1 hour incubations $\left(\Sigma \mathrm{A}, \mathrm{mgC} \cdot \mathrm{m}^{-2} \cdot \mathrm{h}^{-1}\right)\left(\mathrm{r}^{2}=0.76\right.$; $\mathrm{Tab} .1$, regression analysis showed only a minor influence of temperature on integral photosynthesis $\left(r^{2}=0.55\right)$ whereas a higher correlation $\left(r^{2}=0.68\right)$ was found between areal photosynthesis and the surface irradiance as measured during the incubation time $\left(\mathrm{I}_{\mathrm{o}}{ }^{\prime}\right.$ (inc), assuming a $10 \%$ loss through surface reflection; Tab. 1 ). Because water temperature and irradiance was coupled with each other (correlation $\mathrm{T}_{\mathrm{opt}} / \mathrm{I}_{\mathrm{o}}$ ' (inc); Tab.1), partial correlation coefficients for the dependence of areal photosynthesis on radiation alone $\left(\mathrm{r}_{\mathrm{I}}\right)$ and on temperature alone $\left(\mathrm{r}_{\mathrm{T}}\right)$ were determined. Results indicated that $68 \%$ of the variations in areal photosynthesis could be explained by fluctuations in incident radiation $\left(r_{I}=0.68, r_{T}=0.49\right)$. This can be explained by the fact that photosynthesis is temperature-dependent only under conditions of light saturation.

In July and August deep maxima of the chlorophyll-specific assimilation rates appeared. Most of these peaks were found in about $7 \mathrm{~m}$ depth, which was the upper boundary of the deep maximum of chlorophylla. At the same depth $(7-8 \mathrm{~m})$ of this accumulation of Cryptomonas, Oscillatoria and Lyngbya, peaks of the photosynthetic rate could be found as well. The contribution of this low-light adapted phytoplankton assemblage to daily integral primary productivity was $3-9 \%$.

\subsection{Distribution of anoxygenic photosynthesis}

Below $8 \mathrm{~m}$ depth, chlorophyll a comprised only $<8 \%$ of total pigments. Usually, light carbon fixation rates were higher than dark uptake rates which can be attributed to anaplerotic reactions, chemosynthesis and adsorption processes. When the 

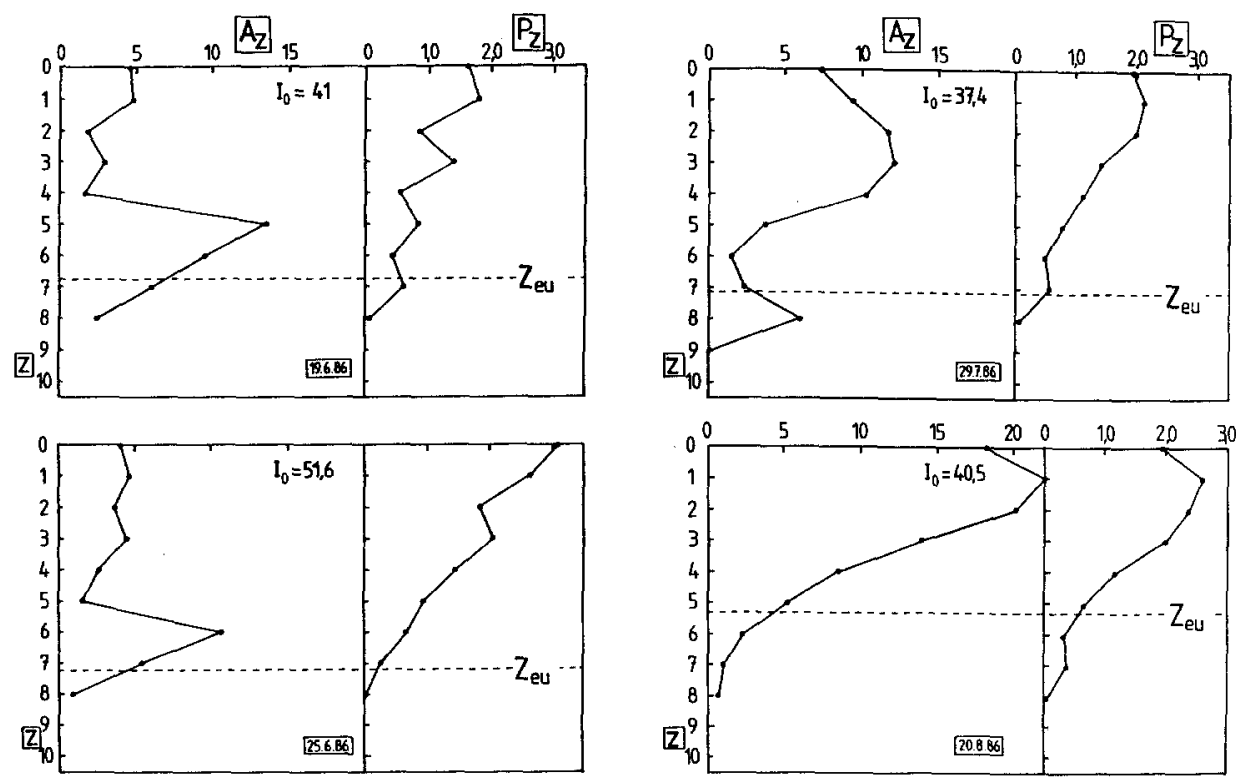

Figure 8. Comparison of vertical distribution of photosynthetic rate $A_{z}$ (in $m g C \cdot m^{-3} \cdot h^{-1}$ ) and chlorophyll-specific photosynthetic rate $\mathrm{P}_{z}\left(\right.$ in $\left.\mathrm{mgC} \cdot(\mathrm{mgChla})^{-1} \cdot \mathbf{h}^{-1}\right)$ for 4 selected dates. Values of incident quantum flux $\left(I_{0}, \operatorname{molPAR} \cdot \mathrm{m}^{-2} \cdot \mathrm{d}^{-1}\right)$ and euphotic depth $\left(\mathrm{z}_{\mathrm{eu}}\right)$ are also given.

lake became mixed in late November, differences between light and dark bottle carbon uptake could no longer be observed (Fig. 9).

To obtain insight into the physiology of the community of phototrophic bacteria, an in situ incubation over the entire water column $(1 \mathrm{~m}$ intervals, Tilzer and Goldman (1978)) and several laboratory incubations under defined conditions $\left(\mathrm{T}=7.3^{\circ} \mathrm{C} ; \mathrm{pH}\right.$ $=7.5$; sulfide concentration $=172 \mu \mathrm{M}$; daylight fluorescent tubes) were conducted using water from $9 \mathrm{~m}$ depth. From the resulting plots of bacteriochlorophyll-specific assimilation rates versus light intensity, light-saturated values of the former $\left(\mathrm{P}_{\mathrm{opt}}\right)$ were determined for a temperature of $7.3^{\circ} \mathrm{C}$ (laboratory incubations) and for $16.5^{\circ} \mathrm{C}$ (in situ incubation). At both temperatures, maximum pigment-specific assimilation rates of anoxygenic photosynthesis were smaller by a factor of 10-20 than those of oxygenic photosynthesis (Tab. 2).

From the beginning of the measurements until the end of October, anoxygenic photosynthesis contributed only $4 \%$ to the total primary production of Mittlerer Buchensee.

\section{Discussion}

Mittlerer Buchensee can be classified as oligotrophic. This assessment is derived from the observed concentrations of soluble reactive phosphorus [SRP: $\left.0.01-0.03 \mu \mathrm{M}\left(=0.31-0.93 \mu \mathrm{g} \cdot \mathrm{l}^{-1}\right)\right]$, and chlorophyll $a$, as well as from photosynthetic rates. 

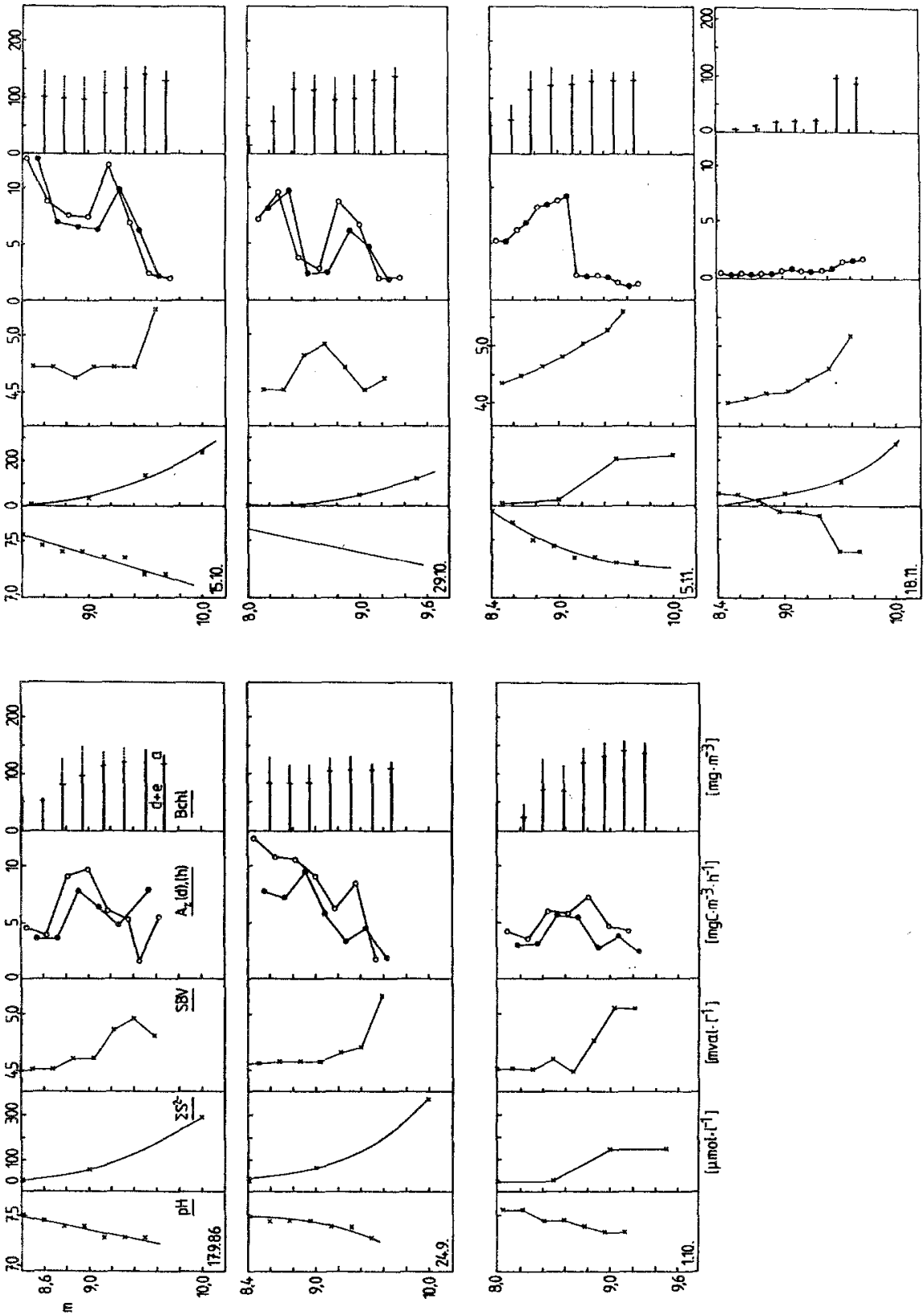

Figure 9. Vertical distribution of photosynthetic activity $\left(\mathrm{A}_{\mathrm{z}}\right)$, bacteriochlorophyll concentration (Bchl $\mathrm{d}+\mathrm{e}, \mathrm{a}$ ), and abiotic factors ( $\mathrm{pH}, \Sigma \mathrm{S}^{=}$: sulfide concentration, SBV: alkalinity) at the oxic/anoxic interface for 7 dates. Open circles $=$ carbon assimilation rates in light bottles $\left(\mathrm{A}_{\mathrm{z}}(\mathrm{h})\right)$, closed circles $=$ carbon assimilation rates in dark bottles $\left(A_{z}(d)\right)$. 
Table 2. Comparison of maximum pigment-specific assimilation rates of oxygenic or anoxygenic photosynthesis $\left(\mathrm{mgC} \cdot \mathrm{mgChl} a^{-1} \cdot \mathrm{h}^{-1}\right.$ or $\left.\mathrm{mgC} \cdot \mathrm{mgBchl}{ }^{-1} \cdot \mathrm{h}^{-1}\right)$ including the respective quantum fluxes $\left(\mathrm{I}_{\mathrm{opt}}\right.$, $\left.\mathrm{mmolPAR} \cdot \mathrm{m}^{-2} \cdot \mathrm{h}^{-1}\right)$.

\begin{tabular}{lcc}
\hline $\mathrm{T}$ & $\begin{array}{c}\text { oxygenic } \mathrm{P}_{\text {opt }} \\
\left(\mathrm{I}_{\text {opt }}\right)\end{array}$ & $\begin{array}{c}\text { anoxygenic } \mathrm{P}_{\text {opt }} \\
\left(\mathrm{I}_{\mathrm{opt}}\right)\end{array}$ \\
\hline $7.3^{\circ} \mathrm{C}$ & 0.77 & 0.038 \\
& $(292)$ & $(46.1)$ \\
$16.5^{\circ} \mathrm{C}$ & 1.66 & 0.17 \\
& $(637)$ & $(60.9)$ \\
\hline
\end{tabular}

In Mittlerer Buchensee, low chlorophyll $a$ concentrations (caused by low nutrient concentrations) together with comparatively high background light attenuation, resulted in low fractional light absorption due to phytoplankton pigments $(17.4 \%)$. By comparison, in a eutrophic Swedish lake, $90 \%$ of underwater light was absorbed by photosynthetic pigments (Ahlgren (1970)). As is shown in Fig. 10, the corresponding low value of light utilization efficiency of photosynthetic organisms in Buchensee $\left(\mathrm{E}_{\mathrm{TOT}}=0.29 \%\right)$ is consistent with data in the literature. Low chlorophyll a concentrations and high background light attenuation are the causes for the low efficiency of energy conversion and hence keep the primary productivity of Mittlerer Buchensee at low levels.

Furthermore, seasonal variations in chlorophyll concentrations were comparatively small (cf. Tilzer 1983, Tilzer and Beese (1988)). The time course of Secchi depth is controlled by factors other than mean chlorophylla concentrations. In Lake Constance, Tilzer (1988) also found weak correlations between Secchi depth and chlorophyll during the winter months when phytoplankton biomass was low. During a three month period in autumn 1986 when cyanobacteria dominated the phytoplankton assemblage, no reasonable estimates of the chlorophyll-specific absorption coefficient $\left(\mathrm{k}_{\mathrm{c}}\right)$ by linear regression analysis were possible. Therefore, light transmission at this time also showed no close relationship to chlorophyll concentrations.

If we assume that the mean vertical light attenuation coefficient over the spectrum of PAR in pure water is $0.12 \mathrm{~m}^{-1}$ (Schanz (1985)), $77 \%$ of non-algal light attenuation $\left(k_{w}=0.530 \mathrm{~m}^{-1}\right)$ in Mittlerer Buchensee can be attributed to gelbstoff and non-algal turbidity. Because of the mostly boggy soils of the drainage area, high concentrations of gelbstoff seem likely. In Lake Constance, gelbstoff and non-algal seston contribute only $56 \%$ to background light attenuation (Tilzer and Beese (1988)). In addition to the variations in quantity and quality of abioseston and dissolved materials, probably also the changes in species composition of phytoplankton are responsible for the observed low correlation between Secchi depth and chlorophyll concentration and for the difficulties in determining $\mathrm{k}_{\mathrm{c}}$. This is reasonable because differences in scattering coefficients of various algae depend on their outer structure (Bricaud et al. (1983), Smith and Baker (1978)).

As indicated by the low impact of phytoplankton pigments on variations of Secchi depth (and sometimes underwater irradiance), self-shading by phytoplankton had negligible effects on the seasonal development of primary productivity in Mittlerer Buchensee. Because of this, no hyperbolic relationship between areal photosyn- 
thesis and mean euphotic chlorophyll concentration as found in nutrient-rich lakes could be demonstrated (Tab. 1, correlation $\Sigma \mathrm{A} / \mathrm{Chla}_{\mathrm{eu}}$ ). Among all variables tested, surface irradiance is the single most important determinant of variations in primary productivity in Buchensee. Only during three weeks between June and July, photosynthetic pigments had some influence on the vertical distribution of photosynthesis (Fig. 8).

The marked thermal stratification and the comparatively low light attenuation due to generally low levels of phytoplankton biomass led to an euphotic zone of 6-7 m thickness until October, which exceeded the depth of the mixed water column (3-4.5 m). On several occasions (e.g. Fig. 8), vertical profiles of photosynthesis showed more than one peak. Sometimes then net photosynthesis was observed at light levels lower than $1 \%$ surface irradiance. Deep maxima of photosynthesis have been shown previously (Tilzer and Goldman (1978), Moll and Stoermer (1982), Walsby and Klemer (1974)). However, in Mittlerer Buchensee areal primary productivity was enhanced only slightly $(3-9 \%)$ by photosynthesis of the deep community of both algae and cyanobacteria (and $4 \%$ due to anoxygenic photosynthesis). High concentrations of chlorophyll $a$ in conjunction with deep maxima of chlorophyll-specific assimilation rates suggested a well-adapted phytoplankton assemblage (Tilzer and Goldman (1978), Perry et al. (1981)).

Low assimilation numbers of phototrophic bacteria were previously observed at the same temperatures by Parkin and Brock (1980) $\left(0.036 \mathrm{mgC} \cdot \mathrm{mgBchl} d^{-1} \cdot \mathrm{h}^{-1}\right)$ and Cloern et al. (1983) $\left(0.069 \mathrm{mgC} \cdot \mathrm{mgBchl} a^{-1} \cdot \mathrm{h}^{-1}\right)$. The vertical sequence of phototrophic organisms in the water column was similar as observed by Dubinina and Gorlenko (1975): Cyanobacteria were shallower than Amoebobacter and Chloronema, which were followed by Pelodictyon and Pelochromatium. Usually, Chromatiaceae occur at shallower depths than Chlorobiaceae which is explained by higher light utilization efficiency and higher tolerance of the Chlorobiaceae towardssulfide (Caldwell and Tiedje (1975), Biebl and Pfennig (1979), Gemerden (1980), Kuenen et al. (1985)).

Similar to the deep populations of phytoplankton, the contribution of anoxygenic photosynthesis to overall primary productivity was small (4\%). In our incubation experiments, maximum bacteriochlorophyll-specific assimilation rates of phototrophic bacteria were reached at irradiances $\left(46.1\right.$ or $\left.60.9 \mathrm{mmolPAR} \cdot \mathrm{m}^{-2} \cdot \mathrm{h}^{-1}\right)$ far in excess of in situ values ( $<<10 \mathrm{mmolPAR} \cdot \mathrm{m}^{-2} \cdot \mathrm{h}^{-1}$ around noon) (Tab. 2). Thus, anoxygenic photosynthesis by phototrophic bacteria always was severely lightlimited.

Takahashi and Ichimura (1968) found bacteriochlorophyll to vary between 19.8 and $828 \mathrm{mg} \cdot \mathrm{m}^{-3}$ and anoxygenic photosynthesis to comprise $9-25 \%$ to total primary production in 10 different Japanese lakes. Similar values have been reported by Parkin and Brock (1980). In meromictic Waldsea Lake, Parker et al. (1983) found bacteriochlorophyll concentrations as high as $392-2325 \mathrm{mg} \cdot \mathrm{m}^{-3}$. Mittlerer Buchensee, by comparison, shows only low concentrations of bacteriochlorophyll. Here, the small extent of the monimolimnion and consequently its severe light limitation (high $\mathrm{k}_{\mathrm{w}}$ and deep position of the anoxyic water layers) can be regarded as one cause for the restricted development of phototrophic bacteria.

The results presented in this study confirm that, similarly to other oligotrophic lakes, the annual cycle of primary productivity was chiefly controlled by abiotic factors 


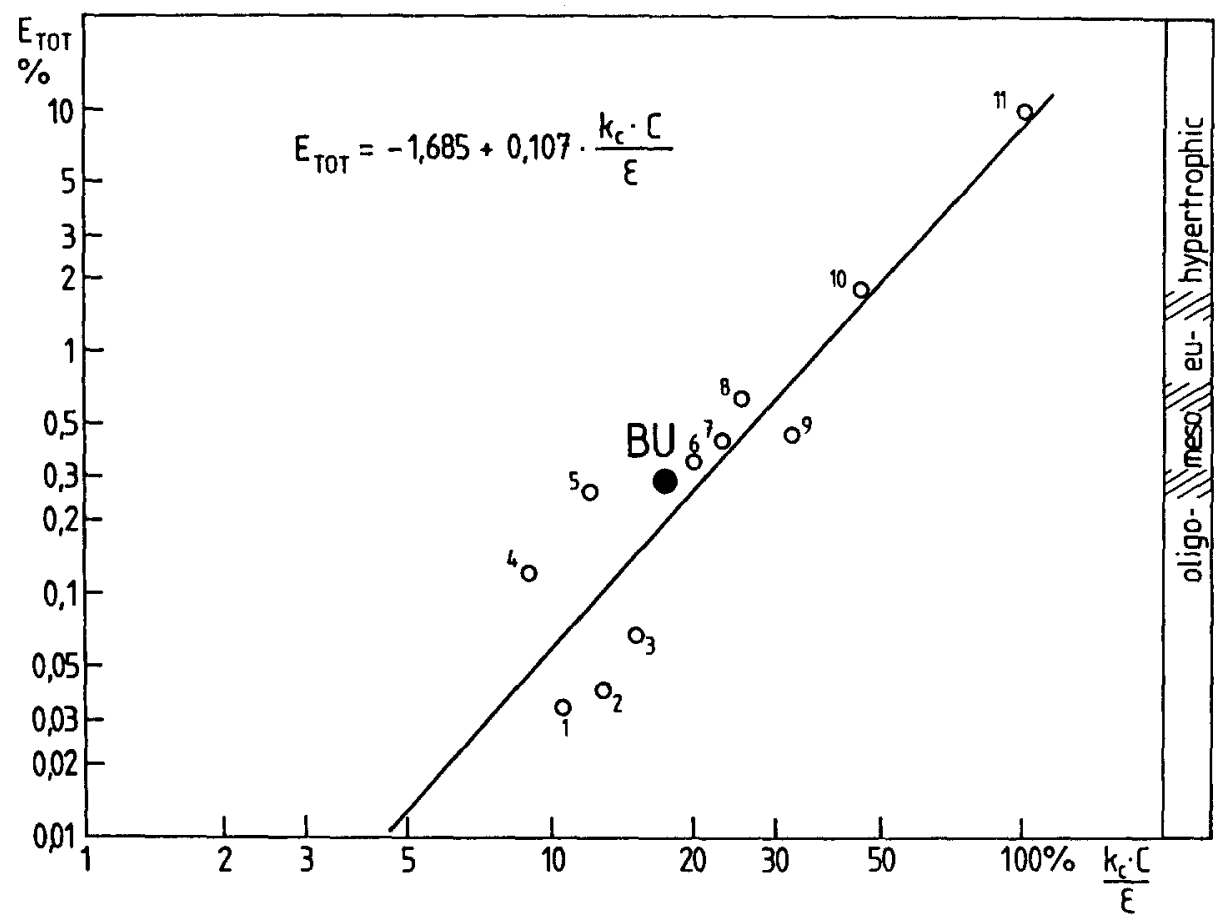

Figure 10. Interdependence between total light utilization efficiency $\mathrm{E}_{\mathrm{TO}}$ and percentage light uptake of phytoplankton $\mathrm{k}_{\mathrm{c}} \cdot \mathrm{C} / \mathrm{k}_{\mathrm{D}}$, calculated using data of different lakes. $1=$ Lake Tahoe (USA), $2=$ Castle Lake (USA, ice-free season only), $3=$ Vorderer Finstertaler See (Austria, ice-free season only), $4=$ Clear $\mathrm{L}$. (USA), $5=\mathrm{L}$. Chad (Chad, Africa), $6=\mathrm{L}$. Kinneret (Israel), $7=\mathrm{L}$. Sammamish (USA), $8=\mathrm{L}$. Constance (West-Germany), $9=$ L. Wingra (USA, ice-free season only), $10=$ Loch Leven (Scotland), $11=$ maximum of the biosphere. BU = data point for Mittlerer Buchensee. Data after Tilzer et al. (1975), Dubinsky and Berman (1981) and Odum (1983).

(Fee et al. (1987)), mainly surface irradiance. Overall light utilization efficiency by phytoplankton is small due to low fractional light absorption by phytoplankton (Fig. 10). In contrast to some other oligotrophic or meromictic lakes (Tilzer and Goldman (1978), Coon et al. (1987), Cloern et al. (1983), Fåafeng (1976)), however, high background light attenuation together with the only weak meromixis resulted in small enhancement of primary productivity by low-light adapted deep-living populations of algae and phototrophic bacteria.

\section{REFERENCES}

Ahlgren, G., 1970. Limnological studies of Lake Norrviken, a eutrophicated Swedish lake. Schweiz. Z. Hydrol. 32: 353-396.

Bannister, T. T., 1974. Production equations in terms of chlorophyll concentration, quantum yield, and upper limit to production. Limnol. Oceanogr. 19: 1-12.

Barthelmeß, T., 1988. Sukzession periphytischer und planktischer Ciliaten und Zooflagellaten im «Mittleren Buchensee» («Güttinger See») unter Berücksichtigung einiger weiterer biotischer und abiotischer Parameter. 223 pp. Diplomarbeit Univ. Konstanz. 
Biebl, H. and N. Pfennig, 1979. Anaerobic $\mathrm{CO}_{2}$ uptake by phototrophic bacteria. A review. Arch. Hydrobiol. Beih. Ergebn. Limnol. 12: 48-58.

Bricaud, A., A. Morel and L. Prieur, 1983. Optical efficiency factors of some phytoplankters. Limnol. Oceanogr. 28: 816-832.

Brunskill, G. J., 1969. Fayetteville Green Lake, New York. II. Precipitation and sedimentation of calcite in a meromictic lake with laminated sediments. Limnol. Oceanogr. 14: 830-847.

Caldwell, D.E. and J. M. Tiedje, 1975. The structure of anaerobic bacterial communities in the hypolimnia of several Michigan lakes. Can. J. Microbiol. 21:377-385.

Caraco, N. and A. H. Puccoon, 1986. The measurement of bacterial chlorophyll and algal chlorophyll a in natural waters. Limnol. Oceanogr. 31: 889-893.

Cloern, J. E., B. E. Cole and R. S. Oremland, 1983. Autotrophic processes in meromictic Big Soda Lake, Nevada. Limnol. Oceanogr. 28: 1049-1061.

Coon, T. G., M. Lopez, P. J. Richerson, T. M. Powell and C. R. Goldman, 1987. Summer dynamics of the deep chlorophyll maximum in Lake Tahoe. J. Plankton Res. 9: 327-344.

Deutsche Einheitsverfahren zur Wasser-, Abwasser- und Schlammuntersuchung, 1982. 3. Auflage, Verlag Chemie Weinheim.

Dubinina, G. A. and V. M. Gorlenko, 1975. New filamentous photosynthetic green bacteria containing gas vacuoles. Mikrobiologiya 44: 511-517.

Dubinsky, Z. and T. Berman, 1979. Seasonal changes in the spectral composition of downwelling irradiance in Lake Kinneret (Israel). Limnol. Oceanogr. 24: 652-663.

Dubinsky, Z. and T. Berman, 1981. Light utilization by phytoplankton in Lake Kinneret (Israel). Limnol. Oceanogr. 26: 660-670.

Eichler, B. and N. Pfennig, 1988. A new purple sulfur bacterium from stratified freshwater lakes, Amoebobacter purpureus. Arch. Microbiol. 149: 395-400.

Einsle, U., 1966. Die Buchenseen bei Radolfzell (Bodensee) und ihr Zooplankton. Mitt. bad. Landesver. Naturkunde u. Naturschutz 9:27-63.

Einsle, U., 1969. Populationsdynamische und synökologische Studien am Crustaceen-Plankton zweier Kleinseen. Beitr. naturk. Forsch. Südw.-Dtl. 28: 53-73.

Fåafeng, B., 1976. En limnologisk undersœkelse av innsjœen Pollen i Ås kommune med hovedvekt på innsjœhistorie og primærproduksjon. Universitetet $i$ Oslo.

Fee, E. J., R. E. Hecky and H. A. Welch, 1987. Phytoplankton photosynthesis parameters in central Canadian lakes. J. Plankton Res. 9: 305-316.

Fitz, R., 1987. Die Sukzession des Phytoplanktons im mittleren Buchensee und ihre Beziehung zu relevanten Umweltfaktoren. Diplomarbeit Univ. Konstanz.

Foy, R.H., 1987. A comparison of chlorophyll a and carotenoid concentrations as indicators of algal volume. Freshw. Biol. 17: 237-250.

French, C.S. and V. K. Young, 1952. The fluorescence spectra of red algae and the transfer of energy from phycoerythrin to phycocyanin and chlorophyll. J. Gen. Physiol. 35: 873-890.

Gemerden, H. v., 1980. Survival of Chromatium vinosum at low light intensities. Arch. Microbiol. 125: $115-121$.

Holler, S., 1987. Untersuchungen zur heterotrophen bakteriellen Produktion des mittleren Buchensee. Diplomarbeit Univ. Freiburg.

Kuenen J. G., L. A. Robertson and H. v. Gemerden, 1985. Microbial interactions among aerobic and anaerobic sulfur-oxidizing bacteria. In: K. C. Marshall (ed.), Advances in Mirobial Ecology, Plenum Press, New York, London: Vol 8, pp. 1-59.

Lorenzen, C. J., 1965. A note on the chlorophyll and phaeophytin content of the chlorophyll maximum. Limnol. Oceanogr. 10: 482-483.

Meffert, M.-E. and J. Overbeck, 1985. Dynamics of chlorophyll and photosynthesis in natural phytoplankton associations. II. Primary productivity, quantum yields and photosynthetic rates in small northgerman lakes. Arch. Hydrobiol. 104: 363-385:

Megard, R. O., W. S. Combs jr., P. D. Smith and A.S. Knoll, 1979. Attenuation of light and daily integral rates of photosynthesis attained by planktonic algae. Limnol. Oceanogr. 24: 1038-1050.

Moll, R. A. and E. F. Stoermer, 1982. A hypothesis relating trophic status and subsurface chlorophyll maxima of lakes. Arch. Hydrobiol. 94: 425-440.

Nusch, E. A., 1980. Comparison of different methods for chlorophyll and phaeopigment determination. Arch. Hydrobiol. Beih. Ergebn. Limnol. 14: 14-36. 
Odum, E. P., 1983. Grundlagen der Ökologie (Deutsche Übersetzung) (part I + II), Thieme, 836 pp.

Overmann, J., 1987. Untersuchungen zu den Produktionsverhältnissen photoautotropher Organismen im Mittleren Buchensee. Diplomarbeit Univ. Freiburg.

Overmann, J. and N. Pfennig, 1989. Pelodictyon phaeoclathratiforme sp. nov., a new brown-colored member of the Chlorobiaceae forming net-like colonies. Arch Microbiol 152: 401-406.

Parker, R. D., J. R. Lawrence and U. T. Hammer, 1983. A comparison of phototrophic bacteria in two adjacent saline meromictic lakes. Hydrobiologia 105: 53-61.

Parkin, T. B. and T. D. Brock, 1980. Photosynthetic bacterial production in lakes: The effects of light intensity. Limnol. Oceanogr. 25: 711-718.

Parkin, T. B. and T. D. Brock, 1981. Photosynthetic bacterial production and carbon mineralisation in a meromictic lake. Arch. Hydrobiol. 91: 366-382.

Perry, M. J., M. C. Talbot and R. S. Alberte, 1981. Photoadaptation in marine phytoplankton: response of the photosynthetic unit. Mar. Biol. 62: 91-101.

Rebsdorf, A., 1972. The carbon dioxide system in freshwater. A set of tables for easy computation of total carbon dioxide and other components of the carbon dioxide system. Freshwater Biological Laboratory, Hillerod, Denmark.

Schanz, 1985. Vertical light attenuation and phytoplankton development in Lake Zurich. Limnol. Oceanogr. 30: 299-310.

Smith, R. C. and K.S. Baker, 1978. Optical classification of natural waters. Limnol. Oceanogr. 23: $260-267$.

Stanier, R. Y. and J. H. C. Smith, 1960. The chlorophylls of green bacteria. Biochim. Biophys. Acta 41: $478-484$.

Steemann-Nielsen, E., 1952. The use of radioactive carbon $\left({ }^{14} \mathrm{C}\right)$ for measuring organic production in the sea. J. Cons. Int. Expl. Mer 18: 117-140.

Steenbergen, C. L. M. and H. J. Korthals, 1982. Distribution of phototrophic microorganisms in the anaerobic and microaerophilic strata of Lake Vechten (the Netherlands). Pigment analysis and role in primary production. Limnol. Oceanogr. 27: 883-895.

Takahashi, M. and S. Ichimura, 1968. Vertical distribution and organic matter production of photosynthetic sulfur bacteria in Japanese lakes. Limnol. Oceanogr. 13: 644-655.

Talling, J. F., 1966. Photosynthetic behaviour in stratified and unstratified lake populations of a planktonic diatom. J. Ecol. 54: 99-127.

Talling, J. F., 1971. The underwater light climate as a controlling factor in the production ecology of freshwater phytoplankton. Mitt. Int. Ver. Limnol. 19: 214-243.

Talling. J. F., 1979. Factor interactions and implications for the prediction of lake metabolism. Arch. Hydrobiol. Beih. Ergebn. Limnol. 13: 96-109.

Tilzer, M. M., 1983. The importance of fractional light absorption by photosynthetic pigments for phytoplankton productivity in Lake Constance. Limnol. Oceanogr. 28: 833-846.

Tilzer, M. M., 1988. Secchi disk-chlorophyll relationship in a lake with highly variable phytoplankton biomass. Hydrobiologia 162: 163-171.

Tilzer, M. M. and B. Beese, 1988. The seasonal productivity cycle of phytoplankton and controlling factors in Lake Constance. Schweiz. Z. Hydrol. 50: 1-39.

Tilzer, M. M., C. R. Goldman and E. de Amezaga, 1975. The efficiency of phytosynthetic light energy utilization by lake phytoplankton. Verh. Int. Verein. Limnol. 19: 800-807.

Tilzer, M. M. and C. R. Goldman, 1978. Importance of mixing, thermal stratification and light adaptation for phytoplankton productivity in Lake Tahoe (California-Nevada). Ecology 59: 810-821.

Walsby, A. E. and A. R. Klemer, 1974. The role of gas vacuoles in the microstratification of a population of Oscillatoria agardhii var. isothrix in Deming Lake, Minnesota. Arch. Hydrobiol. 74: 375-392.

Wetzel, R. G., 1983. Limnology, $2^{\text {nd }}$ ed., Saunders, 767 pp.

Williams, R. B. and M. B. Murdoch, 1966. Phytoplankton production and chlorophyll concentration in the Beaufort channel, North Carolina. Limnol. Oceanogr. 11: 73-82.

Received 21 August 1989;

accepted 15 September 1989. 